\title{
THE CONCEPTUALIZATION OF LIFE IN ENGLISH AND VIETNAMESE PROPAGANDA SLOGANS
}

\author{
Phi Thi Thu Trang* \\ Thang Long University \\ Dai Kim, Hoang Mai, Hanoi, Vietnam \\ Received 29 December 2020 \\ Revised 14 January 2021; Accepted 29 January 2021
}

\begin{abstract}
This paper sets out to examine the conceptualization of life, one of the most complicated concepts that require a number of domains to get mapped, in 600 English and Vietnamse propaganda slogans addressing social policies and purposeful activities in life, mostly collected from street banners and the Internet. The research is based on the principles of the Conceptual Metaphor Theory (Lakoff \& Johnson, 2003) and Metaphor Identification Procedure (Pragglejaz group, 2007; Steen, 1999, 2009). The study aims at finding the conceptual preferences that English-speaking people and Vietnamese people have for life and trying to justify the similarities and differences in the way life is conceptualized in the two languages from social and cultural perspectives. The results suggest that metaphors of life are frequently used in both English and Vietnamese slogans on an almost equal basis. Specifically, life is conceptualized as A LIVING ORGANISM, AN OBJECT, PATH-SCHEMA, BUILDING AND WAR/STRUGGLE and some other isolated domains. Though most source domains are fundamentally similar, the distribution and frequency of use, the number of metaphorical linguistic expressions and even the minor cases reveal a great deal of cultural variation, which is mostly connected with the history of Vietnam and Western countries, and the lifestyles of their people.
\end{abstract}

Key words: conceptual metaphor, conceptualization, life, slogan

\section{Introduction}

In the famous poem The Road Not Taken by Robert Frost, there is a philosophical statement about life: "Two roads diverged in a wood, and I; I took the one less travelled by." Figuratively, the road is symbolic of life and the fork in the wood represents the choices the traveller has to make in his or her life. The question is, why can one understand this poem in this way but not another? That is because of a conceptual metaphor that underlies the expressions in the poem and thereby shapes the way we think: LIFE IS A JOURNEY. Our life is universally conceptualized as a journey in which we start from a particular point (when we are born) and travel to reach a destination (where we want to be in life), and we only stop moving when we die. This is one of the most prevalent conceptualizations of life (Lakofff \& Johnson, 2003; Lakoff \& Turner, 1989; Kövecses, 2002, 2005).

However, LIFE IS A JOURNEY metaphor is only one of many possible ways to conceptualize life. According to Lakoff and

\footnotetext{
Tel: 0985.985.271

Email: fitrang@gmail.com
}

Turner (1989), the target domain of life can be understood through different conceptual sources like BUILDING, GAMBLING GAME, PLAY, STORY, BURDEN, etc. There are two reasons that account for this. First, Kövecses (2002) explains that a single concept lacks the ability of grasping all aspects of such a complex concept as life, resulting in a system of concrete source domains through which intangible things are experienced. Second, metaphor is culturespecific and contextually-influenced (Kövecses, 2005, 2015). He classifies possible causes for different types of metaphorical variations as differential experience and differential cognitive preferences or styles. It is believed that metaphorical conceptualizations emerge from the interaction of different contexts like the physical environment, the social and cultural setting and differential concerns and interests (Benczes \& Ságvári, 2018). As a result, the same underlying conceptual metaphor of life may be realized by a variety of linguistic expressions, which is fundamentally affected by cultures.

Over the last twenty years, the conceptualization of life has been investigated from different angles and in different languages. Most of the research deals with the 
discrepancies between English and another language, and aims at figuring out cultural variations, or investigates how the concept of life is experienced in different types of discourse. A large amount of research on the conceptualization of life has been done through different genres of discourse like essays (Kövecses, 2002, 2005), poems and plays (Tran Thi Lan Anh, 2017; Nguyen Thi Quyet, 2012), song lyrics (Nguyen Thi Bich Hanh, 2015), Holy books (Al-Khaldi, 2014), advertising slogans (Yu, 2009), and even through visual manifestations like paintings (Poppi \& Kravania, 2019), etc. These studies about metaphors of life reveal much of cultural variety in the way life is conceptualized in each language, and more broadly, each culture.

Since we believe that the genre has a great influence on the way life is conceptualized, and slogans are a special discourse genre, we would like to investigate conceptual metaphors of life in English and Vietnamese cultures through propaganda slogans used to address social policies and purposeful activities in life. The concept of life is understood in three ways: the state of being alive (sư sống), the period of time between a person's birth and their death (cuộc dơ $i$ ) and the experience and activities that are typical of all people's existence (cuộc sống) (according to Oxford Advanced Learner's Dictionary, 9th edition). Clearly, life does not only refer to an individual but also a society because people live in a community, which, to some extent, shapes their ways of living. Thus, in this study, the conceptualization of life means that all metaphors related to different aspects of and issues in both individual and social life will be taken into consideration.

To address the conceptualization of life in slogans, two questions are raised:

1) What conceptual preferences do Englishspeaking people and Vietnamese people have for life in slogans and to what extent are they similar and different?

2) What social and cultural aspects could justify those similarities and differences?

\section{Theoretical background}

\subsection{Conceptual metaphor}

Lakoff and Johnson (2003) are considered those who took initiatives in developing the theory of conceptual metaphor, which then became the subjects of many studies carried out by the same writers $(2003,2008)$ and other well-known researchers like Kövecses (2002), Fauconnier (1997), Goatly (1997, 2007), etc. The central point of this theory is to view metaphor as a method of cognition, i.e. we understand one conceptual domain, which is usually more abstract, in terms of another more concrete and familiar conceptual domain (Kövecses, 2002, p. 4). This is realized by the structure A IS B, in which A is the target domain and $\mathrm{B}$ is the source domain; for example, the concept of life is understood through the metaphor LIFE IS A JOURNEY. But in everyday life people do not often say to each other that life is a journey; instead, this metaphor is realized by metaphorical expressions such as: We are at the crossroads of life; He's gone too far; Get out of my way.

However, what sources these expressions are derived from remain a problem. According to Lakoff and Johnson (2003), conceptual metaphors are systematic mappings across conceptual domains. These mappings are the unidirectional correspondences between the source and the target domains. Thanks to this process, the relatively abstract target domain is made more concrete (Kövecses, 2002). For example, some features of the domain JOURNEY are mapped on the the domain LIFE: the travelers are the people, the starting point is the birth, the obstacles encountered are the difficulties met, different routes are different choices, the destination is the goal, and the end of the journey is the death, etc.

In conclusion, conceptual metaphor is one of the forms of conceptualizing the world, a cognitive process that functions as a representation and formation of new concepts without which there will not be new knowledge (Tran Van Co, 2007). As a cognitive tool, it is believed to represent attitudes and convey ideologies and other socio-political constructions through language (CharterisBlack, 2012).

\subsection{Conceptual metaphors and linguistic metaphors}

Even though Lakoff states that "metaphor is fundamentally conceptual, not linguistic, in nature" (1993, p. 244), most of the evidence for conceptual metaphor is based on linguistic data. Even the well-known example taken in the 
classic work Metaphors We Live by (2003) ARGUMENT IS WAR supports the existence of conceptual metaphors with a wide variety of expressions in everyday language such as "Your claims are indefensible", "He attacked every weak point in my argument", or "His criticisms were right on target". Linguistic metaphors are believed to underlie and motivate conceptual metaphors (Lakoff, 1993).

Thus, it is important that linguistic metaphors be identified in order to realize the conceptual metaphor underlying them. Steen (1999, p. 57) claimed that the linguistic examples cited in traditional conceptual metaphor theory literature were produced intuitively and functioned as demonstration; "they have not been systematically and exhaustively collected from large stretches of discourse." Linguistic metaphors that are found in a linguistic dataset play an important role in the construction of conceptual metaphors. Steen $(1999,2009)$ proposed a procedure to decode conceptual mappings from metaphorical expressions in discourse. The five-step method, first introduced in 1999, then revised in 2009, basically is as follows:

- Step 1: Metaphor focus identification, whose aim is to identify metaphorical linguistic expressions;

- Step 2: Metaphorical idea identification, whose aim is to identify the relation between linguistic expressions and the conceptual tenor;

Step 3: Non-literal comparison identification, whose aim is to identify the relation between target domains and source domains;

- Step 4: Non-literal analogy identification, whose aim is to produce an analogy and interpret the metaphor focus;

- Step 5: Non-literal mapping identification, whose aim is to construct the source-target domain mapping.

This procedure is claimed to help the analyst avoid the trap of finding examples to illustrate the well-known conceptual metaphors in previous studies. However, the movement from step 4 to step 5 still depends much on the intuition of the analyst because a linguistic expression may be indicative of more than one conceptual domain. For example, such expressions as attack, win, strategy, etc. may suggest both GAME and WAR domains.

Having said that, linguistic metaphors are closely related to conceptual metaphors. According to Steen (1999), in order to determine a metaphorical expression as part of a general systematic conceptual metaphor, it is essential to analyse a huge amount of data with numerous examples.

\subsection{Cross-cultural variation in metaphor}

Metaphor and culture have long been a concern of many researchers such as Gibbs (1994), Boers (2003), Lakoff and Johnson (2003), Kövecses (2005, 2015), Li (2010), Phan Van Hoa and Ho Trinh Quynh Thu (2017), etc. Many studies that compare metaphors across languages reveal that schematic metaphors are more universally used than specific metaphors, and the more specific a metaphor is, the more culture-specific it becomes. For instance, in Li's comparative research of the metaphor of happiness, besides some widely-used metaphors like HAPPINESS IS UP or HAPPINESS IS A FLUID IN A CONTAINER, $\mathrm{Li}$ finds that HAPPINESS IS OFF THE GROUND is popular in English while HAPPINESS IS A FLOWER IN ONE'S HEART is only used in Chinese. Also, Phan Van Hoa and Ho Trinh Quynh Thu (2017, p. 62), in the study of poetic metaphors of love in English and Vietnamese, suggest that LOVE IS A PLANT is far more popular with novel images in Vietnamese than in English because "Vietnam is a country of rice-based civilization."

Kövecses (2005) and Gibbs (1994) argue that cross-cultural variation in the conceptualization of a thing is the result of different experiences in cultural-social aspects. Moreover, though humans around the world mostly share bodily experiences, their ideology and political-social beliefs differ a great deal, resulting in culture-specific characteristics of metaphors. According to Ly Toan Thang (2015), similarities among metaphors are basic; they just differ in the aspects that are activated, and this depends greatly on cultural variations.

\subsection{Propaganda slogans}

As aforementioned, a large amount of research has shown the importance of taking genre into consideration when studying conceptual metaphor. Slogans are a special kind of discourse with various definitions. Sherif (1937, p. 450) states that "we shall consider a slogan to be a phrase, a short sentence, a headline, a dictum, which, intentionally or unintentionally, amounts to an appeal to the person who is exposed to it to buy some article, to revive or strengthen an already well- 
established stereotype, to accept a new idea, or to undertake some action", which covers the most salient purpose of slogans: to propagate. By taking propaganda slogans addressing social issues and purposeful activities as the material for this study, we expect to see how this genre affects the way life is conceptualized.

\section{The corpus and methodology}

\subsection{The corpus}

This study is corpus-based since corpus methodology has been proposed as one way toward generating a reliable description of the typical context and use of linguistic metaphors (Deignan, 1999; Steen, 1999). A corpus is "any large collection of texts that arise from natural language use" and "data are not invented for the benefit of a model but rather a model emerges from large and representative samples of language" (Charteris-Black, 2004, p. 31). It helps solve the problem of adopting idealized, isolated examples that are purposefully invented by the researchers (Quin, 1991).

The corpus of this study comprises 300 English slogans and 300 Vietnamese slogans which are used to propagate social issues. English slogans are picked up mainly from two websites https://www.thinkslogans.com and https://www.indiacelebrating.com/english-slogans/.

Vietnamese ones are collected from standees, street banners, newspapers and the Internet as well. These slogans focus on social issues like road and labor safety, environment protection, women and children's rights, marriage and family, reading and education, and social problems such as smoking and drugs, prostitution, corruption, bullying, etc., which cover almost all aspects of life. They serve the purpose of propagandas, which aim to raise people's awareness and call them to actions.

Although the corpus is rather small with a limited number of metaphorical expressions, it is expected to make a considerable contribution as starting points in an investigation of a larger corpus because both small and large corpora "are potentially enormously rich sources of data for the metaphor analyst" (Cameron \& Deignan, 2003, p. 151).

\subsection{The methodology}

This study was conducted both qualitatively and quantitatively. First, the Metaphor
Identification Procedure (MIP) suggested by Pragglejaz group (2007) is adopted. We searched for metaphorically-related words by hand since the corpus is small enough, and then used the 5-step identification procedure (Steen, $1999,2009)$ to infer the underlying conceptual metaphors. After that, the metaphors collected will be categorized, analyzed and described in terms of how they are grounded and elaborated, using the contemporary theory of metaphor (Lakoff, 1993). Then the data will be computed quantitatively in order to reveal the frequency and distribution of use of life metaphors in each language. The metaphorical linguistic expressions found in different slogans will be counted, even though they are the same because the repetition of language structures and vocabulary is one typical feature of slogans.

Also, the method of comparison and contrast is employed since this study aims at determining the similarities and differences in the way life is conceptualized in English and Vietnamese slogans. Because conceptual metaphors participate in producing crosscultural variation (Kövecses, 2005), the study tries to demonstrate which source-target mappings are common in the two languages, which correspondences are transferable or not transferable and explain what contexts or experiences ground them. The parameters of comparison exploited in this paper are as follows: 1) the same conceptual metaphors and the same linguistic expressions, 2) the same conceptual metaphors and different linguistic expressions, 3) different conceptual metaphors and linguistic expressions (Gabrys, Solska \& Deignan, 1997). The potential subtle differences will also be evaluated and justified.

\section{RESULTS AND DISCUSSION}

\subsection{An overview of findings}

This section presents the results obtained from a quantitative analysis of the conceptual metaphors of life in English and Vietnamese propaganda slogans. As aforementioned, 300 slogans in each language are taken into consideration, and through manual search we have found 202 metaphors related to life in English slogans and 204 metaphors in Vietnamese ones. This shows that metaphors of life are almost equally frequently used in both languages. Then all the retrieved metaphors are 
classified according to both their level of generality and the source domains. Specifically, life in English and Vietnamese slogans is conceptualized as A LIVING ORGANISM, AN OBJECT, PATH-SCHEMA, BUILDING AND WAR/STRUGGLE. In addition, there are some minor cases labeled as OTHERS because there are insufficient linguistic expressions to generalize detailed conceptual mappings underlying them. However, this group of metaphors will also be investigated because it reveals much of cultural variation.

The following table shows the differences in the distribution and percentage of life metaphors in both corpora.

\section{Table 1}

Conceptual Metaphors for LIFE in English and Vietnamese Slogans

\begin{tabular}{lcc}
\hline \multicolumn{3}{c}{ ENGLISH SLOGANS } \\
\hline \multicolumn{1}{c}{ Source domains } & Number & Percentage \\
\hline LIVING ORGANISM & 24 & $11.88 \%$ \\
OBJECT & 50 & $24.75 \%$ \\
PATH-SCHEMA & 90 & $44.55 \%$ \\
BUILDING & 9 & $4.46 \%$ \\
WAR/STRUGGLING & 22 & $10.89 \%$ \\
OTHERS & 7 & $3.47 \%$ \\
Total & 202 & $100 \%$ \\
\hline
\end{tabular}

\begin{tabular}{lcc}
\hline \multicolumn{3}{c}{ VIETNAMESE SLOGANS } \\
\hline \multicolumn{1}{c}{ Source domains } & Number & Percentage \\
\hline LIVING ORGANISM & 28 & $13.73 \%$ \\
OBJECT & 45 & $22.06 \%$ \\
PATH-SCHEMA & 48 & $23.53 \%$ \\
BUILDING & 29 & $14.22 \%$ \\
WAR/STRUGGLING & 37 & $18.14 \%$ \\
OTHERS & 17 & $8.33 \%$ \\
Total & 204 & $100 \%$ \\
\hline
\end{tabular}

It can be seen from the table that most of the source domains employed to conceptualize life are similar in both English and Vietnamese; they just differ in the OTHERS category, which will be discussed in part 4.2., where a crosslinguistic and cross-cultural comparison is given in more detail. The most favorable source domain is PATH-SCHEMA, but there is quite a big difference in the frequency in that English slogans have 90 cases related to PATHSCHEMA, which accounts for nearly half of all the metaphors found in English and approximately doubles those in Vietnamese. The metaphors LIFE IS A LIVING ORGANISM and LIFE IS AN OBJECT are quite similarly favored in both languages with very little difference in percentages. In contrast, the WAR/STRUGGLE and BUILDING metaphor in Vietnamese are more often used with $18.14 \%$ and $14.22 \%$ respectively while in English, there is only $10.89 \%$ for WAR/STRUGGLE and $4.46 \%$ for BUILDING. We would also like to explain the name of this source: WAR and STRUGGLE are put together since WAR is a sub-type of STRUGGLE and many examples do not directly relate life to war but to some kind of struggle against a disaster or an intangible opponent.

In the next part we are going to compare the use of life metaphors in English and Vietnamese propaganda slogans both linguistically and culturally. Specific linguistic expressions will be taken into account and the similarities and differences in both languages will be discussed, based on culture-specific features. For the convenience of comparison, Vietnamese slogans or metaphorical expressions will be translated literally to English (with further explanation about meaning if necessary) so that the translation does not affect the lexical, or to some extent, grammatical features.

\subsection{Cross-linguistic and cross-cultural comparison}

At the generic-level, both English and Vietnamese exploit the same source domains to conceptualize life; however, at the more specific-level, one can see a number of differences in how distinct aspects of life are conceived.

\subsubsection{LIFE IS A LIVING ORGANISM}

This metaphor is largely ontological. Life is an extremely abstract concept, so it makes more sense when viewing it as something physical and close to us like a living thing which can breathe, eat, or die, or can have blood, roots or diseases. There are two specific-level metaphors derived from the source of living things: HUMANS ARE PLANTS and PROBLEMS IN LIFE ARE DISEASES. In those propaganda slogans, problems in life refer to social ones like poverty, corruption, unsafety, war, drugs and smoking, etc. The metaphorical expressions of LIFE IS A LIVING ORGANISM metaphor are presented in the following table. 
Table 2

Metaphorical Expressions of LIFE IS A LIVING ORGANISM in English and Vietnamese Slogans

English thrive, sow, seed (2), reap (2), healthy, plant, predator, suffer, grow (2), strong, dangerous, virus, cure, medicine (3), vaccine, perish, flourish (2), bud, bloom, flower, nourish, prevention, disease, breed, rot, harvest

Vietnamese lành mạnh (healthy) (3), gốc rễ (root), (2), nhân (kernel), máu (blood), nhu cầu (need), hơi thở (breath), măng non (bamboo sprout), búp trên cành (bud), giống nòi/nòi giống (breed) (3), nguyên khí (vitality), nuôi dưỡng (nourish), trồng (plant), tế bào (cell) (2), tươi đẹp (fresh/beautiful) (2), mồ chôn (tomb) (2), tàn (fade/wither)

Note: the number in brackets indicates the number of occurrences of the item.

From the results retrieved from our manual search, it is clear that many English expressions have Vietnamese equivalents: healthy (lành mạh), nourish (nuôi duõng), plant (trồng), bud (búp), breed (giống nòi), etc, but many do not. Vietnamese slogans often use plant-related or animal-related nouns and adjectives while English slogans tend to use more verbs. For example, a Vietnamese slogan says "Nước là máu của sụ sống" (Water is the blood of life), but an English slogan would go "Allow life to thrive, don't drink and drive." This could be justified with the difference between Western culture where positive action (tung) is favored and Eastern culture where passiveness (ching) prevails ( $\mathrm{Li}$ Ta-chao, quoted in The Last Confucian: Liang Shu-ming and the Chinese Dilemma of Modernity, Alitto, 1986).

Another difference is that there is no metaphor of PROBLEMS IN LIFE ARE DISEASES in Vietnamese. Instead, Vietnamese slogans often refer to problems in life as a disaster or an enemy, which belongs to the field of war and struggle. For instance, while English-speaking people view corruption as " $a$ disease having no medicine", in Vietnamese, it is more common to see "Thưc hành tiết kiệm, phòng chống tham nhũng, chống lãng phî" (Practice thrift, stave off corruption, fight against wastefulness), "Thuốc là là kẻ thù của sức khỏe" (Smoking is an enemy against health) or "hiểm hoa tai nạn giao thông" (the disaster of traffic accidents). This is going to be discussed in the section about the WAR/STRUGGLE metaphor.

\subsubsection{LIFE IS AN OBJECT}

Another ontological metaphor that is prevailing is LIFE IS AN OBJECT. Objectifying an abstract concept is salient in our conceptual system, because it gives us a chance to sense, quantify, rank, measure, etc., it (Lakoff and Johnson, 2003). Slogans, with its outstanding feature of conciseness, objectify life as a tangible thing so that the audience can visualize it more vividly.

\section{Figure 1}

The System of LIFE IS AN OBJECT Metaphor in English and Vietnamese Slogans

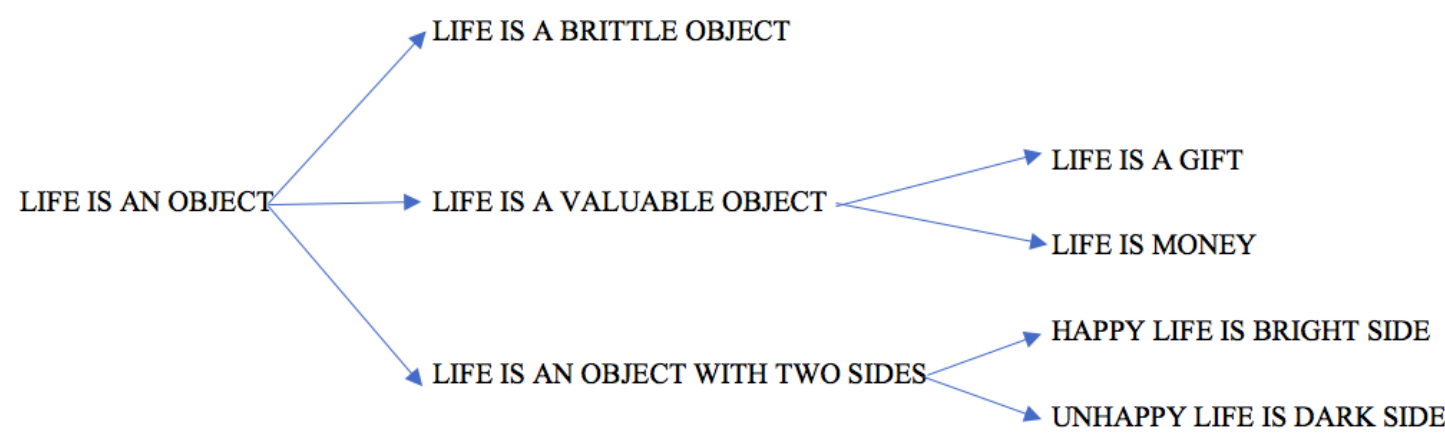

The following list of metaphorcial expressions realizing LIFE IS AN OBJECT proves that life is conceptualized and expressed in almost the same way in the two languages: 
Table 3

Metaphorical Expressions of LIFE IS AN OBJECT in English and Vietnamese Slogans

\begin{tabular}{|c|c|}
\hline English & $\begin{array}{l}\text { gift (6), give , break, pay (3), save (3), cost (2), hand over, pay heavy fees, throw away, trash, } \\
\text { count, cut, bleak, waste (5), conserve, spend (2), shine, bright (3), destroy, steal, precious, } \\
\text { treasure, keep, pass on, valued, devalue, pro-life, light, shape, cherish, rich (2), precious, how } \\
\text { many, share, secure, brighter, gain, own, stolen, worth, utilize, pricey }\end{array}$ \\
\hline Vietnamese & $\begin{array}{l}\text { nếp (sống) (crease - referring to a habit) (3), văn minh (radiant - referring to a civilized world) } \\
\text { (7), đánh mất (lose), đảm bảo (ensure), bảo vệ (protect) (6), cướp đi (rob) (2), tươi sáng (bright) } \\
\text { (3), bảo tồn (preserve), phá tan (break), giá trị (value) (2), trong tay (in hand), chất lượng } \\
\text { (quality) (5), sàng lọc (screen), đẹp (beautiful), có ích (helpful), của cải (riches), cứu (save), } \\
\text { chia sẻ (share) (2), kết nối (connect), gửi (send/give), trao (hand over), lưu giữ (store), tỏa sáng } \\
\text { (shine), yêu thương (love), giữ gìn (keep), ý nghĩa hơn (more meaningful), thắp (light), đốt } \\
\text { (ngắn) (burn something short) }\end{array}$ \\
\hline
\end{tabular}

Note: the number in brackets indicates the number of occurrences of the item.

Most of the linguistics expressions in both languages are equivalents. One can find the idea of "saving life" or "cost life" easily in such English slogans as "Save water, Save life" or "Trying to make up time could cost your life". Similarly, they are also ubiquitous in Vietnamese as in "Cho giọt máu, cúu cuộc đời" (Give blood, save life) or "Tai nạn giao thông hàng năm cướp đi sinh mạng của hàng ngàn nguo'i" (Every year traffic accidents cost/steal thousands of lives). It can be concluded that LIFE IS AN OBJECT, and more specifically LIFE IS A VALUABLE OBJECT is very common in both languages. For people of each culture, life is so precious and fragile that they treasure it like a possession, which results in a very high frequency of use of such words as "save" and "(don't) waste".

The only minor difference noticed when LIFE IS AN OBJECT WITH TWO SIDES metaphor is examined is that in Vietnamese slogans, unhappy life as the dark side of an object is not mentioned, and there is only one example in the English corpus as in "Leaks make your future bleak". It is supposed that slogans are made to encourage and motivate people to live well rather to warn them of an unhappy future.

\subsubsection{THE PATH-SCHEMA METAPHOR}

The PATH-SCHEMA is one of the most popular image-schema metaphors, which are particularized as IN-OUT, FRONT-BACK, UPDOWN, CONTACT, MOTION and FORCE (Kövecses, 2002). In slogans, we realize that the SOURCE-PATH-GOAL schema dominates. This metaphor is specified as LIFE IS A VERTICAL PATH and LIFE IS A JOURNEY. Crossculturally and cross-linguistically, these

metaphors derive from the EVENT STRUCTURE metaphor (Lakoff, 1993).

LIFE IS A VERTICAL PATH is actually an orientational metaphor in which GOOD THINGS IN LIFE ARE UP and BAD THINGS IN LIFE ARE DOWN, which are in accordance with the metaphors GOOD IS UP and BAD IS DOWN suggested by Lakoff and Johnson (2003). However, the number of these metaphors in English slogans is fairly larger than in Vietnamese one, and one can find both directions up and down in English but only up in Vietnamese.

\section{Table 4}

Metaphorical Expressions of LIFE IS A VERTICAL PATH in English and Vietnamese Slogans

\begin{tabular}{cc}
\hline English & $\begin{array}{c}\text { down (6), evolve up, rise, raise, up } \\
\text { (5), tear down, build up, stand (2), } \\
\text { uphold, arise, elevate, drag down, } \\
\text { high, higher, stand up, fall (2), lift up }\end{array}$ \\
\hline Vietnamese & $\begin{array}{c}\text { trên (hết) (above all), nâng cao (uplift) } \\
\text { (7), vun đắp (build up), vươn tới đỉnh } \\
\text { cao (reach for the top), vươn cao } \\
\text { (rise), cao đẹp (lofty/elevated), lên } \\
\text { (up) }\end{array}$ \\
Note: the number in brackets indicates \\
the number of occurrences of the
\end{tabular}


Meanwhile, LIFE IS A JOURNEY is a structural metaphor, which constructs LIFE as a path with a starting point and a destination. As Johnson (2013) argues, one of the most important conceptualizations that people use to make sense of life refers to a PURPOSIVE ACTIVITY in terms of MOVING FORWARD TOWARD A DESTINATION. In this process, different aspects of a journey are taken into account.

Table 5

The Mappings of LIFE IS A JOURNEY Metaphor

\begin{tabular}{cc}
\hline JOURNEY (source) & LIFE (target) \\
\hline $\begin{array}{c}\text { movement along the } \\
\text { path }\end{array}$ & living a life
\end{tabular}
path

starting to go

starting a life event

destination

purpose of life

different routes

different choices

obstacles on the path

difficulties in life

companions

support

length of the journey

length of life

\section{Examples}

(E) If someone is going down the wrong road, he doesn't need motivation to speed him up. What he needs is education to turn him around.

(V) Giọt máu cho đi, cuộc đời ở lại (Blood given, Life stays)

(E) Life is very short, so put worries apart and give your life a kick start.

(V) Thay đổi văn hoá giao thông, bắt đầu từ chính bạn (To change traffic culture, start from you.)

(E) Education is a right path to reach to the destination.

(V) Hướng tới một xã hội không có trẻ em nghèo khó và thất học (Head for a society without poverty-stricken and illiterate children).

(E) Take a better route, put that smoke out.

(V) Nơi nào có ý chí, nơi đó có con đường (There’s a will, there's a path)

(E) We shall overcome.

(V) Lớp tôi thống nhất đạp đổ thách thức (Our class is determined to overthrow challenges)

(E) Good books are good companions.

(V) 55 năm công tác dân số đồng hành cùng hạnh phúc mỗi gia đình (55 years of population and family planning goes together with every family's happiness)

(E) Life's short. Don't rush it.

(V) Nhanh một phút, chậm cả đời. (1 minute faster, one life slower)

motions changes

(E) What goes around comes around: Keep the sea clean. * No Vietnamese examples

These different mappings are expressed via a number of metaphorical linguistic items, demonstrating the complexity and diversity of this metaphor of life.

\section{Table 6}

Metaphorical Expressions of LIFE IS A JOURNEY in English and Vietnamese Slogans

English lead the way, reach, journey, destination, lead (6), on the brink, go (4), go around (2), come around (2), take positive steps, rough, stop (7), advance, get on the right track, end, short (2), long, a kick start, rush, way (3), walk in different directions, walk in, walk out, get, go side by side, guide, at right path (2), reach to the destination, go down, road, speed up, turn around, track, block (2), go forward, step (2), place (3), line, fill, go forth, bring ahead, drive,

companions, take ... places, sail away, sail on a sea, exceed, put an end (2), keep on track, come first, come second, come up on the short end, put a step back, leave behind, rewind, route, come, join the race, carry on, step up, step on, overcome

Vietnamese bắt đầu (start) (2), đi đôi (go side by side) (2), nhanh (fast), chậm (slow), hướng đến/hướng tới (head for) (3), nhịp cầu (bridge), đồng hành ( $g$ o together), từng bước (step by step), chặng đường (path), thi đua (race), đạp đổ (overthrow), con đường (path), tiếp sức (relay), vững bước (step firmly into), tiến bộ (progress) (3), lùi (step back), đi (go), ở (stay), thúc đẩy (push forward), điểm tựa (fulcrum), đây lùi (push backward), bờ vực (brink), về (return), dừng lại (stop), dẫn đến (lead to)

Note: the number in brackets indicates the number of occurrences of the item. 
As aforementioned in the overview, the most notable difference in the use of the PATHSCHEMA metaphor in English and Vietnamese slogans lies in the number of cases. 90 metaphors are found in English while there are only 48 in Vietnamese. Table 6 also suggests that there is a much wider variety of metaphorical expressions of this metaphor of life in English slogans than in Vietnamese ones. It could be indicated that English-speaking countries are closely associated with movements and exploration. In the past, they travelled everywhere to explore new worlds, and this imprinted the notion of life as a journey or an adventure in their minds. On the contrary, the term "luỹ tre làng" (village's bamboo fence) surrounding Vietnamese communities hint that they prefered stability to movement. This could probably be verified, as Kövecses suggested in his study (2005) that cultural history plays a central part in shaping the conceptualization of life.

\subsubsection{LIVING IS STRUGGLING AND LIVING IS BUILDING}

The reason why we put these two metaphors in the same discussion is that they go together and share the same features. As figured out through our investigation, these metaphors in Vietnamese outnumber those in English. From a cultural and historical perspective, Vietnamese people have a strong mindset about fighting and building. They have a long-standing history of fighting against invaders and developing countries after war. Therefore, in Vietnamese slogans, it is easy to encounter such phrases as "Sống, chiến đấu và làm việc ..." (Live, fight and work ...) or "Xây dựng nếp sống văn hoá ..." (Build a civilized way of life ...). However, it is undeniable that both languages share the same conceptual metaphor of life.

Table 7

The Subtypes of LIVING IS STRUGGLING AND BUILDING Metaphor

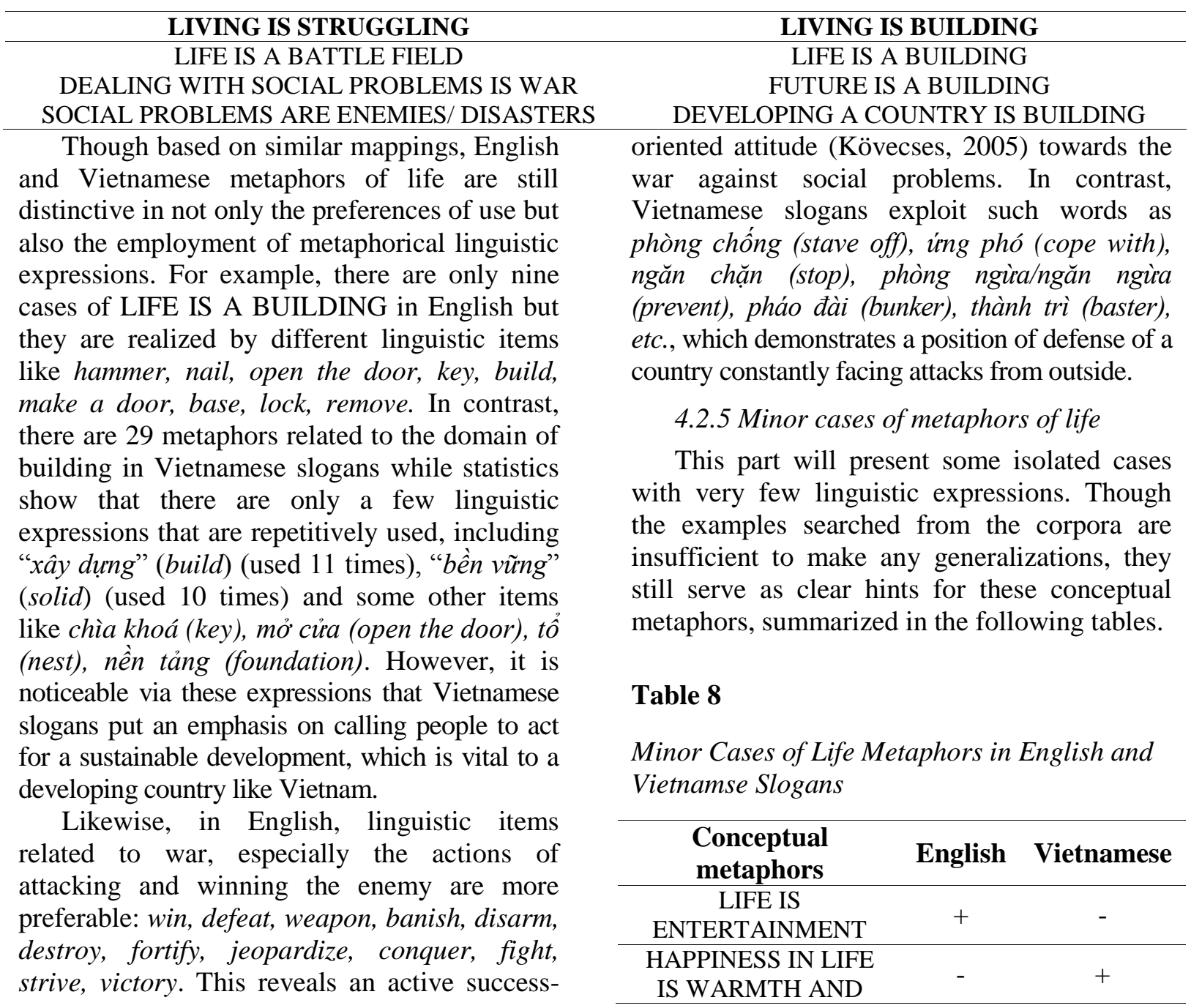




\begin{tabular}{ccc}
\hline FULLNESS & & \\
\hline HUMAN ARE TOOLS & - & + \\
\hline LIFE IS BUSINESS & - & + \\
\hline $\begin{array}{c}\text { Note: }+ \text { (existent); }- \\
\text { (non-existent) }\end{array}$ & Total: 7 & Total: 17 \\
\hline As Kövecses pointed out in his study
\end{tabular}
(2005), there is a tendency of American people using positive domains, which originated in the consumption-oriented culture of the $20^{\text {th }}$ century America, to conceptualize life, and we reckon that this is also true for Englishspeaking countries in general because consumerism caused widespread "leisure time" values to Western Europe and the United States at the turn of the $20^{\text {th }}$ century (Veblen, 1899). Hence, it is not surprising to know that life to them is viewed as entertainment. In the English corpus, we found these: When you gamble with safety you bet your life (LIFE IS A GAMBLING GAME), Life is a game, play it happily (LIFE IS A GAME), Character is best shown when nobody is watching (LIFE IS A PLAY). However, with a country that experienced numerous wars and difficulties in the past like Vietnam, life is contrastive to entertainment; it is a struggle. To the Vietnamese people, happiness in life is having enough food ((ăn) no - (eat to) full), and warm clothes (ám - warm). It is therefore common practice to use the phrase "no âm" (full and warm) to express happiness in Vietnamese. Also, experiencing severe hardships in life leads to the idea of humans as tools which need to be rèn (forged) and luyện (refined) as in Rèn thầy truớc, luyện trò sau (Forge teachers first, Refine students later).

Surprisingly, LIFE IS BUSINESS metaphor does not exist in English slogans while hinted in Vietnamese ones with the term of dầu tur (invest) like in Đầu tư cho con người là đầu tu' cho turong lai tuooi sáng của dân tộc (Investing in people is investing in the bright future of the nation). Vietnam is now a fast-growing economy, it is understandable that business terms go into life; however, we cannot produce any explanation for the non-existence of this metaphor in English slogans at the moment, which requires further research.

\section{Conclusion}

The results of this study and the discussion have made it clear that even though English and
Vietnamese slogans contain the same genericlevel conceptual metaphors of life such as LIFE IS A LIVING ORGANISM, LIFE IS AN OBJECT, LIFE IS A PATH, LIVING IS STRUGGLING AND LIVING IS BUILDING, there are still a number of differences at a more specific level, in the frequency of use and metaphorical linguistic expressions, which are susceptible to cultural and historical influences. There are some specific-level metaphors which exist in one language but not in the other like LIFE IS ENTERTAINMENT, SOCIAL PROBLEMS ARE DISEASES in English or HAPPINESS IN LIFE IS WARMTH AND FULLNESS, HUMAN ARE TOOLS, LIFE IS BUSINESS in Vietnamese. Together with the detailed analysis of metaphorical linguistic expressions and the number of occurrences of specific items, the study shows that Englishspeaking people view life from a more dynamic and success-oriented perspective while Vietnamese people perceive it more statically, protectively and hopefully. It is, therefore, evident that our study results have made a meaningful contribution to the understanding of conceptual metaphors in general and the conceptualization of life in English and Vietnamese in particular, for those who are interested in English and Vietnamese languages and cultures.

\section{REFERENCES}

\section{Vietnamese}

Lý Toàn Thắng (2015). Ngôn ngũu học tri nhận - Nhũng nội dung quan yếu. Nxb Khoa học xã hội.

Nguyễn Thị Bích Hạnh (2015). Ân du tri nhận trong ca tù Trịnh Công Sonn (chuyên khảo). Nxb Khoa học xã hội.

Nguyễn Thị Quyết (2012). Ẩn dụ ý niệm về cuộc đời trong thơ tiếng Anh và tiếng Việt. Ngôn ngũu, (6), 19-29.

Trần Thị Lan Anh (2017). Ân du ý niệm trong tho và kịch Luu Quang Vũ [Luận án Tiến sĩ Ngữ văn, Trường Đại học Sư phạm Hà Nội].

Trần Văn Cơ (2007). Ngôn ngũ học tri nhận (Ghi chép và suy nghĩ). Nxb Khoa học xã hội.

\section{English}

Al-Khaldi, Y. A. Y. (2014). The metaphorical concept "Life is water" in the Holy Qur'ān: A cognitivesemantic approach [Unpublished non-thesis paper]. Al-Imam Muhammad Ibn Saud Islamic University. https://www.academia.edu/6647922

Alitto, G. (1986). The last Confucian: Liang Shu-ming and the Chinese dilemma of modernity. University of California Press. 
Benczes, R., \& Ságvári, B. (2018). Life is a battlefield: Conceptualizations of life among Hungarian adults. Society and Economy, 40(4), 571-586. https://doi.org/10.1556/204.2018.40.4.6

Boers, F., \& Littlemore, J. (Eds.) (2003). Cross-cultural differences in conceptual metaphor: Applied linguistics perspectives. Special edition of Metaphor and Symbol, 18(4).

Cameron, L., \& Deignan, A. (2003). Combining large and small corpora to investigate tuning devices around metaphor in spoken discourse. Metaphor and Symbol, 18(3), 149-160

Charteris-Black, J. (2004). Corpus approaches to critical metaphor analysis. Palgrave Macmillan.

Charteris-Black, J. (2012). Forensic deliberations on "purposeful metaphor". Metaphor and the Social World, 2(1), 1-21.

Deignan, A. (1999). Linguistic metaphors and collocation in non-literary corpus data. Metaphor and Symbol, 14(1), 19-38.

Fauconnier, G. (1997). Mappings in thought and language. Cambridge University Press.

Gabrys, D., Solska, A., \& Deignan, A.(1997). Teaching English metaphors using cross-linguistic awarenessraising activities. ELT journal, 51(4), 352-60.

Gibbs, R. (1994). The poetics of mind: Figurative thought, language, and understanding. Cambridge University Press.

Goatly, A. (1997). The language of metaphors. Taylor \& Francis Routledge.

Goatly, A. (2007). Washing the brain-Metaphor and hidden ideology. John Benjamins Publishing Company.

Johnson, M. (2013). The body in the mind: The bodily basis of meaning, imagination, and reason. University of Chicago Press.

Kövecses, Z. (2002). Metaphor: A practical introduction. Oxford University Press.

Kövecses, Z. (2005). Metaphor in culture: Universality and variation. Cambridge University Press.

Kövecses, Z. (2015). Where metaphors come from: Reconsidering context in metaphor. Oxford University Press.

Lakoff, G. (1987). Women, fire, and dangerous things. The University of Chicago Press.
Lakoff, G. (1993). The contemporary theory of metaphor. In A. Ortony (Ed.), Metaphor and thought (pp. 202-251). Cambridge University Press.

Lakoff, G., \& Johnson, M. (2003). Metaphors we live by (2nd ed.). Oxford University Press.

Lakoff, G., \& Turner, M. (1989). More than cool reason: A field guide to poetic metaphor. The University of Chicago Press.

Li, X. (2010). A comparative analysis of English and Chinese idioms - From the perspective of conceptual metaphor of "happiness". Journal of Language Teaching and Research, 1(4), 473-476.

Phan, V. H., \& Ho, T. Q. T. (2017). Poetic metaphors of love in English and Vietnamese. VNU Journal of Foreign Studies, 33(6), 56-64. https://doi.org/10.25073/2525-2445/vnufs.4208

Poppi, F., \& Kravania, P. (2019). Sic vita est: Visual representation in painting of the conceptual metaphor LIFE IS A JOURNEY. Semiotica, (230), 541-566. https://doi.org/10.1515/sem-2018-0009

Pragglejaz Group (2007). MIP: A method for identifying metaphorically used words in discourse. Metaphor and Symbol, 22(1), 1-39.

Quinn, N. (1991). The cultural basis of metaphor. In J. W. Fernandez (Ed.), Beyond Metaphor: The theory of tropes in anthropology (pp. 56-93). Stanford University Press.

Sherif, M. (1937). The psychology of slogans. Journal of Abnormal and Social Psychology, 32(3-4), 450-461.

Steen, G. (1999). From linguistic to conceptual metaphor in five steps. In R. Gibbs \& G. Steen (Eds.), Metaphor in cognitive linguistics (pp. 57-78). John Benjamins.

Steen, G. (2009). From linguistic form to conceptual structure in five steps: Analysing metaphor in poetry. In G. Brône \& J. Vandaele (Eds.), Cognitive poetics: Goals, gains and gaps (pp. 197-226). Mouton De Gruyter.

Veblen, T. (1899). The theory of the leisure class: An economic study of institutions. Macmillan.

Yu, C. (2009). Metaphors in food advertising slogans. Retrieved November 6, 2018, from http://hkr.divaportal.org/smash/get/diva2:293746/FULLTEXT01 


\title{
SỰ Ý NIỆM HOÁ CUỘC SỐNG TRONG KHẨU HIỆU TUYÊN TRUYỀN TIẾNG ANH VÀ TIẾNG VIỆT
}

\author{
Phí Thị Thu Trang \\ Đại học Thăng Long \\ Đại Kim, Hoàng Mai, Hà Nội, Việt Nam
}

Tóm tắt: Bài viết trình bày kết quả nghiên cứu về sự ý niệm hoá life (sư sống, cuộc sống, cuộc đời) trong 600 khẩu hiệu tuyên truyền tiếng Anh và tiếng Việt được sưu tầm từ các băng rôn, biểu ngữ trên đường phố và mạng Internet. Nghiên cứu được thực hiện dựa trên khung lý thuyết về ẩn dụ ý niệm của Lakoff và Johnson (2003), sử dụng quy trình nhận diện ẩn dụ ý niệm của nhóm Pragglejaz (2007) và nhà nghiên cứu Steen (1999, 2009) nhằm tìm ra các ẩn dụ về cuộc sống được người bản ngữ sử dụng trong khẩu hiệu, đồng thời tìm cách lý giải cho những điểm tương đồng và dị biệt trong cách ý niệm hoá cuộc sống ở hai ngôn ngữ từ góc độ xã hội và văn hoá. Kết quả cho thấy ẩn dụ ý niệm về cuộc sống được sử dụng với tần suất cao trong cả khẩu hiệu tiếng Anh và tiếng Việt, với các miền nguồn chung như CƠ THỂ SỐNG, VẬT THÊ, LƯỢC ĐỒ ĐƯỜNG ĐI, XÂY DỰNG, CHIÊN TRANH/ĐẤU TRANH. Mặc dù vậy, sự phân bố tỉ lệ ở mỗi miền nguồn, số lượng các biểu thức ngôn ngữ và các tiểu loại ẩn dụ có sự khác biệt tương đối rõ nét, phản ánh sự biến thiên văn hoá liên quan đến lịch sử và lối sống của con người Việt Nam và các nước phương Tây.

Từ khoá: ẩn dụ ý niệm, ý niệm hoá, cuộc sống/cuộc đời, khẩu hiệu 